Sultan Qaboos University Journal of Arts \& Social Sciences

جامعة السلطان قابوس الإداب مجلة الآداب والعلوم الاجتمأعية

\title{
Description of Number, Person and Tense Features in the Verbal Morphologies of Jibbāli and Lari
}

\author{
Khalsa Al Aghbari \\ Assistant Professor \\ Department of English Language \\ and Literature, College of Arts and Social \\ Sciences, Sultan Qaboos University \\ khalsah@squ.edu.om
}

\begin{tabular}{c}
\hline Muhammad Ourang \\
\hline PhD candidate \\
University of New South Wales \\
Sydney, Australia \\
m.ourang@student.unsw.edu.au
\end{tabular}




\title{
Description of Number, Person and Tense Features in the Verbal Morphologies of Jibbāli and Lari
}

\author{
Khalsa Al Aghbari and Muhammad Ourang
}

\section{Abstract:}

The study describes a few linguistic features in the verbal morphologies of two understudied languages: Jibbāli and Lari. Jibbāli, a Modern South Arabian language spoken in the southern part of the Sultanate of Oman and Lari, an Indo-Iranian language spoken in Iran, are at risk of being endangered due to the facts that (1) they lack a writing system, (2) they are not taught at schools, (3) they are not the official languages in Oman and Iran and, most importantly, (4) there is no effort recorded to preserve these languages. Therefore, the study aims at exposing the linguistic richness of Jibbāli and Lari through describing the tendencies of their verbal morphologies. This may help revitalize a substantial linguistic aspect of these languages. However, since this study is limited in space, it only focuses on certain morphological features which make these languages stand out. The researchers observe a few undocumented linguistic tendencies in Jibbāli and Lari which may attract attention for further studies. For example, Lari, unlike other Iranian languages, lacks an auxiliary on the progressive tense which is largely expressed via morphemes. Jibbāli also exhibits some linguistic tendencies manifested by having a pronoun that refers to the speaker and another (exclusive) person in the conversation. Jibbāli is also characterized by abundant verbs which exhibit internal change along with a few affixes. Where relevant, features from the verbal morphologies of the two languages are delineated with examples collected through fieldworks and personal communication. Findings revealed that Lari is, by and large, a linear language in which affixes dock on bases to express grammatical contrasts while Jibbāli is highly inflectional with verbal affixes (number, person and tense) and morpho-phonological changes. In addition, affixes were found to play a crucial role in marking tenses and mood in Lari while Jibbāli employed a dual system in marking number.

Keywords: Jibbāli, Lari, verbal morphology, number, person, language documentation

\section{الخصائص اللغوية الفريدة في تصريف أفعال الجبالية واللارية}

\author{
خالصة الأغبري ومحمد أورنج
}

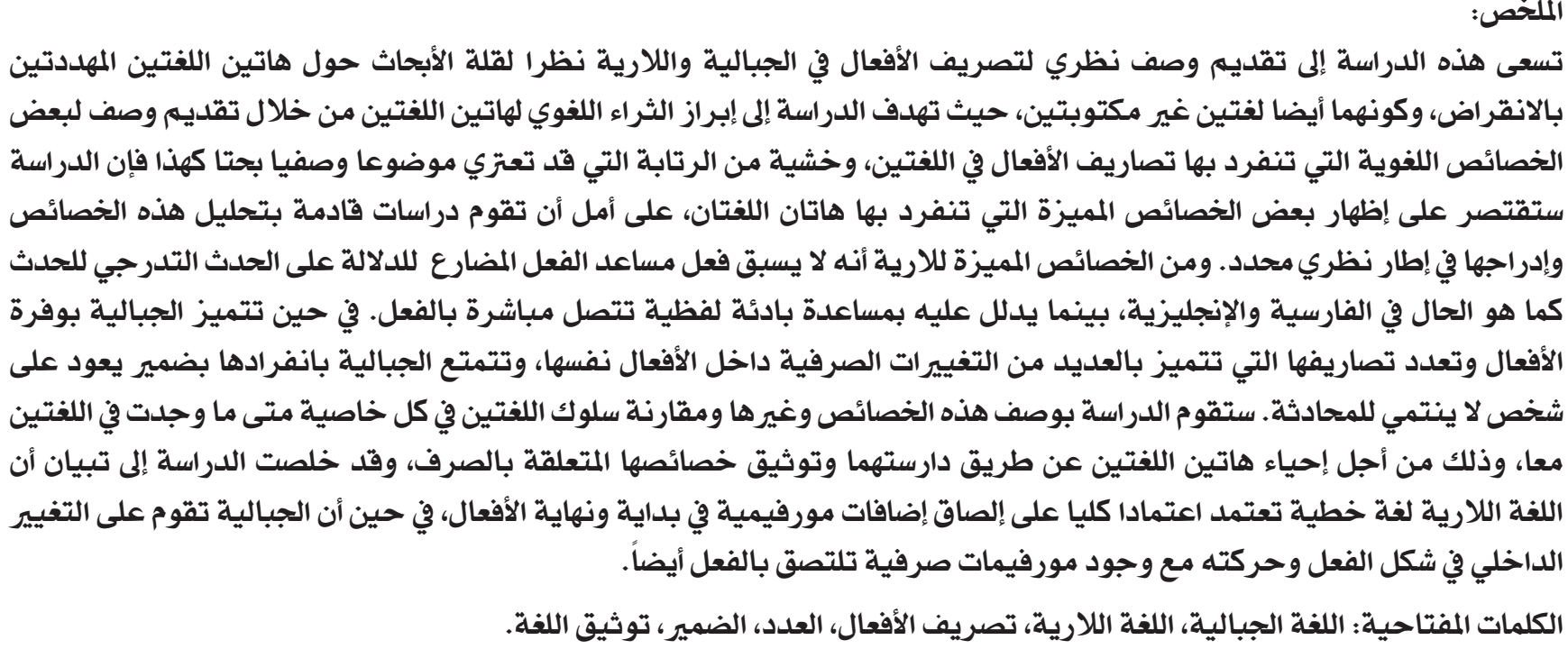




\section{Introduction}

The paper aims to document and describe a few linguistic features in the verbal systems of Lari and Jibbali. Therefore, it is a descriptive account that highlights the features that characterize the verb in these languages. Some of the highlighted features are observed to be rare cross-linguistically. This may help attract further linguistic studies on these languages. To do so, the linguistic features of the verbal systems of Lari are described first, followed by discussing the parallel features (if present) in Jibbāli, then the dual features were tabulated for further study.

By describing the linguistic aspects of Lari and Jibbali, this paper will contribute to increaseing the body of linguistic data currently available for these endangered languages. Moreover, it will document aspects of the verbal systems of these endangered languages with the goal of making data available for inclusion in encyclopedias and special dictionaries on Jibbāli and Lari. This may potentially aid theoretical linguists to develop analyses of these languages. The study will also increase the materials sought for language pedagogy. As it brings these endangered languages into sharper focus, possible aspects can be examined and given as a corpus for teachers, researchers and other sources of instruments. In bringing these two unrelated languages in a single study, we aim to highlight similarities and differences on the verbal morphologies of Lari and Jibbāli.

2. Introducing Jibbāli and Lari linguistically and geographically

In this section, we first introduce the geographic locations of Jibbāli and Lari. Then, we explain the linguistic and geographical backgrounds of Oman and Iran with the goal of revealing how Jibbāli and Lari are at the risk of being endangered. Special emphasis is given to their linguistic status.

Lari belongs to the southwestern branch of Middle Iranian Languages (Abolghasemi 2010). It is spoken in a large area in Iran including Fars province which includes Larestan Township, Ahel City and Kal Village. It also exists in a small area of Hormozgan province which comprises the cities of Bastak, Jenah and Lengah. Lari is the mother tongue of a large number of speakers in some Arabic-speaking countries too like the United Arab Emirates, Qatar, Bahrain, Kuwait, and Oman (Vosoughi 2006). It is estimated that approximately 600,000 people speak Lari as a mother language.

Jibbāli, on the other hand, is a Modern South Arabian language (henceforth, MSA) which belongs to the west Semitic branch (Rubin 1997). It is spoken by 30,000 to 50,000 Jibbāli speakers (Rubin 2014) who live in Dhofar in the southern part of Oman. Jibbāli is also reported to be spoken in Yemen (Lonnet, 1985:50; Hofstede, 1998: 13). It has three dialects known as eastern, western and central. Scholars of Jibbāli often study the central dialect following Johnstone (1981) who considered it to be the mother Jibbāli.

Oman is a linguistically rich country. There are plenty of languages and dialectal varieties of Omani Arabic spoken across its lands (Holes 1989, Glover 1988, Shaaban 1977). For instance, in the North of Oman, Omanis speak Kumzari, an Endo-Iranian language. In the South of the country, people speak Jabbali, Mehri and Harsusi languages. Swahili, Lawati and Balushi are minority languages in Oman. Despite this fact, the official language in Oman is Arabic. It is the language of government, education and worship. It is also the language of mass media, official ceremonies and religious and public speeches (Shaaban 1977). The second widely accepted language is English. Therefore, there is little attention given to the numerous languages in the country. People are allowed to informally practice these languages but jobs always seek knowledge of Arabic and English. Therefore, speakers of these languages view them as useless in Oman where more prestige is given to Arabic and English. This leads to the endangerment of these languages.

One may think that Jibbāli is not an endangered language as parents continue to teach it to their children as a mother tongue. However, based on an academic reference, Jibbāli is listed as 'vulnerable' in the "Ethnologue: Languages of the World, 16th Edition (2009)" where only 25,000 people are reported to continue to speak it to date. Moreover, through personal communication with young speakers, we observe that these speakers always claim that their Jibbāli is not as real and representative of true Jibbāli as the old generations'. They constantly took our linguistic queries to their parents and grandparents, revealing insufficient knowledge of the language. One young speaker of Jibbāli went as far as claiming that her pronunciation of the language was intangible to her parents and grandparents.

Lari is considered to be a 'definitely endangered language' by the 'UNESCO Atlas of the World's Languages in Danger'. It is also thought to be one of the twenty-one endangered Iranian languages. This is due to the fact that the official language of Iran is 
Persian. Lari is never listed as official; languages such as Azeri, Kurdish and Tati are more commonly used than Lari.

\section{Theoretical Framework}

This research utilizes a combination of descriptive and contrastive approaches in grammar-writing. Gleason (1961) states that the contrastive approach in grammar writing focuses mainly on the construction patterns of language in comparison. It is useful in developing and designing materials of second language learning. The difficulties of statements of the target language will be revealed in such a grammar, and the teacher can select the best strategy to meet and eradicate these problems. Descriptive methods of writing grammar on which contrastive grammar is based brings adequate description of the two languages contrasted. The description must be proper to the languages being described. It is a system that records the structural patterns discernible with corpus. It does not evaluate patterns in terms of any non-linguistic factors. Moreover, not all patterns or continuations of patterns used have the same social significance (pp. 207-8).

Therefore, the study considers the tenses including the past, present and future in detail. The grammatical tenses are defined and the structure dominant on them is explained. It should be mentioned that the table related to each tense is represented for more elaboration. Finally, the findings are discussed.

\section{Literature Review}

4.1 Scholarship on the Verbal Morphology of Lari Although there are some linguistic research on Lari, it is incomplete as it only provides an insecure basis for linguistic generalization. It is also inadequate for the purposes of preservation, both for the community of linguists and for the Lari people themselves. For example, only grammatical descriptions were written about the language (e.g. Koji Kamioka 1979; Vosughui 2006; Eghtedari 1990 \& 2005; Khonji 2009). Moreover, a handful of published articles can be found in the available linguistic literature. Nevertheless, none of this can be safely considered as an adequate, comprehensive, or general reference on Lari. Khonji's grammar succinctly describes the dialect of Khonj and Lari, but it limits the description of the language to morphology; it fails to address the phonological, phonetic, syntactic or semantic aspects of Lari. In addition, it pays little attention to lower levels of grammar and suffers from severe inadequacies in transcription because it does not employ the IPA.

\subsection{Scholarship on the Verbal Morphology of Jebbāli}

The verbal morphology ${ }^{1}$ of Jibbāli has been explored in Johnstone (1980b and 1968), Testen (1992), Hayword et al (1988) and Rubin (2014). Each of these works focus on a different aspect of the verbal system except for Rubin who devoted lengthy pages to describe both the verbal stem and verbal conjugations. Below, we review these works in detail.

In the verbal paradigms of Semitic languages, the t-prefix marks the 2 nd and certain 3rd person forms. Johnstone (1980b and 1968) observes that there is a t-prefix loss in two Modern South Arabian languages: Socotri (1968) and Jebbāli (1980b). While Jebbāli and Socotri exhibit a t-prefix loss in certain verbal themes including the indicative, subjunctive and conditional forms of causative verbs, intensive-conative verbs, quadri-literal verbs and passive verbs, Socotri also elides this prefix in the reflexive and hollow verbs. Johnstone (1980b) presents lengthy paradigms of these themes proving that there is a systematic loss of the t-prefix. He explains that this loss represents a well-marked feature of Jebbāli and Socotri, especially in 3rd feminine singular, 2nd masculine and feminine singular and plural. He further shows that Jebbāli subjunctive and conditional passive forms extends this loss to the non-occurrence of the $\mathrm{i}-/ \mathrm{j}$ - prefix and the n-prefix of the first person plural. He finally draws the conclusion that Jebbāli and Socotri are closely related and this phenomenon indicates "the possibilities of the Semitic verb extension and change" (Johnstone 1980b: 470).

Testen (1992) offers a phonological analysis of the phenomenon of the loss of the t-prefix in Socotri and Jebbāli mentioned in Johnstone (1968 and 1980b). He thoroughly investigates the types of verbs that exhibit truncation of the $t$ - prefix and divides them into two classes: verbs preserving $t$ - and verbs lacking t-. According to Testen, although these two classes seem to "consist of apparently arbitrarily delineated set of stem-types" (Testen 1992: 447), this random classification becomes justifiable when comparing them with their stem-types cognates of Literary Arabic. He observes that Jebbāli and Socotri truncate the person marker $t$ from verbs whose cognates in Literary Arabic have the pre-radical vowel /u/. He then explains the loss of the t- prefix from phonological and historical perspectives pointing out that the t-less forms result from a change in the initial sequence tu- 
to a simple vowel in the course of the morphological development of the verb. The loss does not happen when the pre-radical vowel is /a/. Testen also explains why $\mathrm{j}$ - and $\mathrm{n}$ - disappear from the passive paradigm of Jebbāli. He shows that while Jebbāli consistently loses the t-prefix before $/ \mathrm{u}$ / in open syllables, it also loses $\mathrm{j}-, \mathrm{n}-$, and perhaps the glottal stop in closed syllables. According to Testen, this analysis allows us to list Jebbāli and Socotri alongside Arabic and Akkadian, providing evidence that early Semitic distinguishes between the pre-radical vowels $/ \mathrm{u} /$ and $/ \mathrm{a} /$ in the prefixed tenses of the verbs.

Hayword et al's study (1988) on the vowels contained in the verbal paradigm in Jebbāli was inspired by Johnstone's introduction in his Jebbāli lexicon (1981). That introduction describes two conjugational classes $(C(A)$ : $C ə C \supset C$ and $C(B)$ : CéC $C C$ ) of the simple verbs in Jebbāli. These classes mainly differ in the shape the third person masculine singular takes in the perfective, imperfective and subjunctive forms. While most verbs can be classified under these two classes, Johnstone notes that verbs whose consonantal roots are characterized by weak radicals, gutturals or / $\mathrm{b} /$ and $/ \mathrm{m} /$ have idiosyncrasies and may thus diverge from the two classes. Hayword et al, focus on the effect of gutturals contained in the roots of some verbs on the vowels. After establishing the underlying canonical forms of the simple verbs in Jebbāli, Hayward et al, intensively discuss how the vowels contained in verbs with gutturals differ. They also discuss the effect of accent placement of the nature of the surface form of the verb. Towards the end of their study, they manage to linearly derive a small subset of verbs with gutturals. I consider this study to be quite systematic. It also lists a number of phonological processes in the language which have direct bearing into the verbal paradigm of the language.

In his book on Jibbāli, Rubin (2014) elaborated on the linguistic tendencies of verbal stem and verbal conjugations of the language, with illustrative examples. He devoted two lengthy chapters to discuss verb stems, classes and forms detailing the phonology involved in their conjugations. He also highlights the morphological features of weak verbs in the language.

\section{Data Collection}

The primary source for Lari data is the material gathered by the researcher during a fieldwork in Lari speaking Districts in Iran during the period from 2011 to 2014. The second author, who is a native speaker of Lari, also consulted handwritten pages of Lari speakers, recordings and notes received by Lari researchers on the verbal system of this endangered language as well as available books about the language. It is worth noting that the data gathered were classified first, then transcribed in IPA (International Phonetic Alphabet) and next checked with native speakers. Also, the tape recordings were reviewed to ensure the gathered data conform to the language. In some cases, the writers of Lari books were interviewed for further information on the subject.

As for Jibbāli, the first author relied on two major sources: fieldwork in 2014 and Rubin (2014). The fieldwork continued for five months (about 3 to 4 hours per day). It involved interviews with native speakers of the language. The authors are not speakers of Jibbāli but one of them teaches Jibbāli students who were willing to spare 3 to 4 hours after classes to discuss linguistic patterns in the language.

Since the study is meant to highlight a few linguistic features that feature in the verbal systems in Lari and Jibbāli, readers are referred to Rubin $(2014)^{2}$ for substantially informative description of the verbal system in the language. The authors here only selected a handful of linguistic peculiarities and aims to develop a theoretical analysis of these in subsequent studies. After data were collected through the aforementioned methods (fieldwork and interviews), they were described in their respective sections based on the categories discussed. Having tabulated the data in the two languages, the linguistic features can be described and the ubiquitous characteristics are analyzed. Doing so, untouched areas of the verbal systems in Lari and Jibbāli could be taken into sharper consideration.

\section{6 . Findings}

The verbal system of Lari is very ubiquitous (Khonji, 2009) and completely different from Persian; for example, the present continuous tense in Lari is made without any auxiliary whereas the auxiliary is needed in Persian and English. The inflectional morpheme of -âm is added to infinitives like [t]edæ] 'to go' and the present continuous of [t]edâm] 'I'm going' is made consequently. So, the tense employs an affix rather than a separate auxiliary.

Jibbāli has an imperfect tense which indicates the progressive tense. According to Rubin (2014: 142), the imperfective "can, in various contexts, indicate almost any tense or aspect. It can be used as a general, habitual, or immediate present; a habitual past; a future; a present or past progressive; or a circumstantial complement." Similar to Lari, Jibbāli 
Table (1): Number and person for (ondæ) 'to come' and (dedæ) 'to see' in Lari

\begin{tabular}{|l|l|l|l|l|}
\hline Num./ Per. & Lari & Gloss & Lari & Gloss \\
\hline $1^{\mathrm{ST}} / \mathrm{SG}$ & ondəm & I came & omdı & I saw \\
\hline $2^{\mathrm{ND}} / \mathrm{SG}$ & ondə) & you came & otdı & you saw \\
\hline $3^{\mathrm{RD}} / \mathrm{SG}$ & omæ & he/she came & ofdı & he/she saw \\
\hline $1^{\mathrm{ST}} / \mathrm{PL}$ & ondəm & we came & modı & we saw \\
\hline $2^{\mathrm{ND} / \mathrm{PL}}$ & ondı & you came & todı & you saw \\
\hline $3^{\mathrm{RD}} / \mathrm{PL}$ & ondət & they came & fodı & they saw \\
\hline
\end{tabular}

attaches affixes (more specifically prefixes $d$ - and $\delta^{-}$-) on the imperfective to mark the progressive tense as in t̄̄k 'are crying'. The morphology of verbs in Jibbāli is quite complex as it involves the addition of many prefixes and suffixes which may be deleted under certain phonetic circumstances.

\subsection{Number and person}

In Lari, number is manifested through inflectional morphemes (i.e. suffix). The number in Lari, as other Iranian languages, include singular and plural. For example, 'æt $\int \mathrm{m}^{\prime}$ ' [I go] is a verb made of æ $+\mathrm{t}$ ] + om; the suffix -om shows that the verb has the conjugation for the singular. In addition, the suffix-om also indicates the first person. Therefore, both person and number, in Lari, are inherently represented via suffixes. Table (1) shows some examples for person and number in different tenses.

As seen in the table, the inflectional suffixes on the verbs indicate person and number and depend on the transitivity/intransitivity of the verb. This means different tenses show different inflectional morphemes and the grammatical tense is determined by the person and number. Concerning the transitivity/intransitivity of the verb, it should be said that transitive verbs show the number and person as prefixes [e.g., Jodı] but the intransitive ones represent these two features as suffixes [e.g., ondət]. Some examples are provided below:

(1) Oniya æma Jodı

"they saw us."

(2) Æli xoy æsæn ondət

"Ali and Hasan came."

Jibbāli, on the other hand, makes a three-ways number distinction: singular, plural and dual. Table (2) shows parallel conjugations for the verbs [nk'ə؟] 'come' and [ten] 'see'. Similar to Lari, Jibbāli also marks verbs
Table (2): Number and person for ( $\left.\mathrm{nk}^{\prime} \partial \varsigma\right)$ 'to come' and (ten) 'to see' in Jibbāli

\begin{tabular}{|c|c|c|c|c|}
\hline Num./ Per. & Jibbāli & Gloss & Jibbāli & Gloss \\
\hline $1^{\mathrm{ST}} / \mathrm{SG}$ & $n k ı ə\left\{k^{\prime}\right.$ & I came & tenaks & I saw \\
\hline $2^{\mathrm{ND}} / \mathrm{SG} / \mathrm{M}$ & nkıəৎk' & you came & tenak & you saw \\
\hline $2^{\mathrm{ND}} / \mathrm{SG} / \mathrm{F}$ & nkıəৎif & you came & tenif & you saw \\
\hline $3^{\mathrm{RD}} / \mathrm{SG} / \mathrm{M}$ & $n k ı ə \varsigma$ & he came & teni & he saw \\
\hline $3^{\mathrm{RD}} / \mathrm{SG} / \mathrm{F}$ & nkıəৎot & she came & tenot & she saw \\
\hline $1^{\mathrm{ST}} / \mathrm{PL}$ & nkıəৎan & we came & tenan & we saw \\
\hline $2^{\mathrm{ND}} / \mathrm{PL} / \mathrm{M} \& \mathrm{~F}$ & nkıəSom & you came & tenk'om & you saw \\
\hline $2^{\mathrm{ND}} / \mathrm{PL} / \mathrm{F}$ & nkıəイan & you came & tenk'an & you saw \\
\hline $3^{\mathrm{RD}} / \mathrm{PL}$ & nikıəৎ & they came & teni & they saw \\
\hline
\end{tabular}

Table (3): Jibbāli pronominal features

\begin{tabular}{|c|c|c|c|}
\hline Person & Singular & Dual & Plural \\
\hline 1 & he? & lh & nћan \\
\hline $2 m$ & hat & Tih & tum \\
\hline $2 f$ & hit & & tan \\
\hline $3 m$ & fah & Jih & Jum \\
\hline $3 f$ & sah & & san \\
\hline
\end{tabular}

by suffixes. But, Jibbāli incurs internal changes into the verbs. This can be seen in some verbs where an inserted vowel plus a suffix mark conjugations.

Jibbāli also has dual features which are not listed in the table above. This is because it has some gaps in the 2 nd and 3 rd dual feminine. Table (3) shows the pronominal paradigm of Jibbāli. The paradigm is quite full in its contrastive features but lacks the 2 nd and 3 rd dual feminine which are expressed using the plural.

One of the peculiarities of Jibbāli's pronominal paradigm involves the inclusion of a pronoun that references the speaker with another person in the conversation. It means "I and another person but not you". According to native speakers of Jibbāli, this pronoun surfaces more often in accusations when an interlocutor accuses an addressee of doing something. The addressee then uses the 1st person pronoun to say that he with another person in the conversation were out or doing something else. The 1st person pronoun also surfaces when a speaker tells the group that he and another person share a secret or were at a certain place lately. The following sentence illustrates this pronoun:

tih āyad

We (dual) - go-past

We went

6.2 Mood 


\subsubsection{Present and past subjunctive mood in Lari} In Lari, the rule for making this tense is different for present and past tenses. To illustrate, for making the subjunctive mood of the present tense, it is enough to replace the prefix a- from the present simple with the prefix be-. Then, suffixes are added accordingly. In addition, the conjugation of transitive and intransitive verbs are different in that the former accepts both suffixes and prefixes in making the mood, while the latter just takes prefixes (Mirdehghan and Ourang, 2013). Table (4) shows an example.

Some examples are provided below:

(1) Belke bftom enæ næye

"if you can't help me, I would fail."

(2) Enæ ændeJ, tæ bonom

"if you come, I can see you."

To make the subjunctive mood of past tense in Lari, other prefixes are added to the past stems. These affixes are different for transitive and intransitive verbs. To illustrate, the intransitive verbs only get suffixes whereas the transitive ones take prefixes and suffixes simultaneously.

Table (5) presents these verbs in detail.

The story in Jibbāli is quite different and strikingly contrary to what is expected. Despite the fact that Jibbāli is a non-concatenative and highly inflectional when compared to Lari, Jibbāli uses a free standing form (not an affix) to express the subjunctive mood. Moreover, it does not make any distinction between the present and past subjunctive moods. Below, I show an example in Table (6):

An example is provided below:

(1) zæng fæ mæzo bælke xætezbe "do not call him. Maybe he is slept."

As seen in Table [7], Jibbāli uses /her/ to refer to 'if' which indicates a subjunctive mood. /her/ precedes the verb which takes its usual conjugations to indicate the subjunctive mood.

\section{Conclusion}

This study was an attempt to document a few of linguistic features in the verbal morphologies of Lari and Jibbāli, languages believed to be understudied and endangered due the fact that they are unwritten, they are not considered to be official languages in Oman and Iran, and there is no serious move by the governments to preserve these languages. Part of the description done here is to highlight these languages to revitalize them and draw attention to their linguistic richness. It has been shown that Lari is
Table (4) Present subjunctive mood of [æftezæ] 'to fall' \& (dezæ) 'to see' in Lari

\begin{tabular}{|c|c|c|c|c|}
\hline \multicolumn{5}{|c|}{ Present Subjunctive Mood } \\
\hline \multirow{2}{*}{$\begin{array}{l}\text { PER/ } \\
\text { NUM }\end{array}$} & \multicolumn{2}{|c|}{ Intransitive verbs } & \multicolumn{2}{|c|}{ Transitive verbs } \\
\hline & Lari & English & Lari & English \\
\hline $1^{\mathrm{ST}} / \mathrm{SG}$ & beftom & (if) I fall & bebenom & (if) I watch \\
\hline $2^{\mathrm{ND}} / \mathrm{SG}$ & beftef & (if) You fall & bebeneJ & (if) You watch \\
\hline $3^{\mathrm{RD}} / \mathrm{SG}$ & befte & $\begin{array}{l}\text { (if) } \mathrm{He} / \mathrm{She} \\
\text { falls }\end{array}$ & Bebene & (if) He/She watches \\
\hline $1^{\mathrm{ST}} / \mathrm{PL}$ & beftem & (if) We fall & bebenem & (if) We watch \\
\hline $2^{\mathrm{ND}} / \mathrm{PL}$ & befti & (if) You fall & Bebeni & (if) You watch \\
\hline $3^{\mathrm{RD}} / \mathrm{PL}$ & beftet & (if) They fall & bebenet & (if) They watch \\
\hline
\end{tabular}

Table (5) Past subjunctive mood of / xæteæ/ (to sleep) \& / letæ/ [to pour] in Lari

\begin{tabular}{|c|c|c|c|c|}
\hline \multicolumn{5}{|c|}{ Past Subjunctive Mood } \\
\hline \multirow{2}{*}{ PER/NUM } & \multicolumn{2}{|c|}{ Intransitive verbs } & \multicolumn{2}{|c|}{ Transitive verbs } \\
\hline & Lari & English & Lari & English \\
\hline $1^{\text {ST }} / \mathrm{SG}$ & xætezbom & (if) I fell & omletezbe & (if) I poured \\
\hline $2^{\mathrm{ND}} / \mathrm{SG}$ & xætezbe & (if) You fell & otletezbe & (if) You poured \\
\hline $3^{\mathrm{RD}} / \mathrm{SG}$ & xætezbe & $\begin{array}{l}\text { (if) } \mathrm{He} / \mathrm{She} \\
\text { fell }\end{array}$ & ofletezbe & $\begin{array}{l}\text { (if) } \mathrm{He} / \mathrm{She} \\
\text { poured }\end{array}$ \\
\hline $1^{\mathrm{ST}} / \mathrm{PL}$ & xætezbem & (if) We fell & moletezbe & (if) We poured \\
\hline $2^{\mathrm{ND}} / \mathrm{PL}$ & xætezbi & (if) You fell & toletezbe & (if) You poured \\
\hline $3^{\mathrm{RD}} / \mathrm{PL}$ & xætezbet & $\begin{array}{l}\text { (if) They } \\
\text { fell }\end{array}$ & Joletezbe & (if) They poured \\
\hline
\end{tabular}

Table (6) Present and past subjunctive mood of /gə $9 a r /$ (to fall) \& / fhal/ (to pour) in Jibbāli

\begin{tabular}{|c|c|c|c|c|}
\hline \multicolumn{5}{|c|}{ Present and Past Subjunctive Mood } \\
\hline $\begin{array}{l}\text { PER/ } \\
\text { NUM }\end{array}$ & Jibbāli & English & Jibbāli & English \\
\hline $\begin{array}{l}1^{\mathrm{ST}} / \\
\mathrm{SG}\end{array}$ & $\begin{array}{l}\text { her } \\
\text { gəSarak }\end{array}$ & (if) I fall/ fell & $\begin{array}{l}\text { her } \\
\text { Jhalak }\end{array}$ & (if) I pour/ poured \\
\hline $\begin{array}{l}2^{\mathrm{ND} /} \\
\mathrm{SG}\end{array}$ & $\begin{array}{c}\text { her } \\
\text { gəYarak }\end{array}$ & $\begin{array}{l}\text { (if) You fall/ } \\
\text { fell }\end{array}$ & $\begin{array}{l}\text { her } \\
\text { Shalak }\end{array}$ & $\begin{array}{l}\text { (if) You pour/ } \\
\text { poured }\end{array}$ \\
\hline $\begin{array}{l}3^{\mathrm{RD}} / \\
\mathrm{SG}\end{array}$ & $\begin{array}{l}\text { her } \\
\text { gəSarot }\end{array}$ & $\begin{array}{l}\text { (if) } \mathrm{He} / \mathrm{She} \\
\text { falls/ fell }\end{array}$ & $\begin{array}{l}\text { her } \\
\text { fhalot }\end{array}$ & $\begin{array}{c}\text { (if)He/She pours/ } \\
\text { poured }\end{array}$ \\
\hline $\begin{array}{l}1^{\mathrm{ST}} / \\
\mathrm{PL}\end{array}$ & $\begin{array}{l}\text { her } \\
\text { gəSarat }\end{array}$ & $\begin{array}{l}\text { (if) We fall/ } \\
\text { fell }\end{array}$ & $\begin{array}{l}\text { her } \\
\text { fhalat }\end{array}$ & $\begin{array}{l}\text { (if) We pour/ } \\
\text { poured }\end{array}$ \\
\hline $\begin{array}{l}2^{\mathrm{ND}} / \\
\mathrm{PL}\end{array}$ & her gə५ar & $\begin{array}{l}\text { (if) You fall/ } \\
\text { fell }\end{array}$ & her fhal & $\begin{array}{l}\text { (if) You pour/ } \\
\text { poured }\end{array}$ \\
\hline $\begin{array}{l}3^{\mathrm{RD}} / \\
\mathrm{PL}\end{array}$ & $\begin{array}{c}\text { her } \\
\text { gəSarkom }\end{array}$ & $\begin{array}{l}\text { (if) They fall/ } \\
\text { fell }\end{array}$ & $\begin{array}{c}\text { her } \\
\text { fhalkom }\end{array}$ & $\begin{array}{l}\text { (if) They pour/ } \\
\text { poured }\end{array}$ \\
\hline
\end{tabular}

an affixation language that expresses verbal contrasts by linearly docking affixes on stems. It is less complex than Jibbāli which makes use of both affixation and internal change. Jibbāli, being a Semitic language, always incurs changes into the internal structure of the verb to mark differences in grammar. Affixes are attached but are not enough without certain changes 
happening concomitantly. The paper also revealed inconsistencies on the subjunctive mood in Lari and Jibbāli. It showed that Jibbāli, contrary to what is expected, uses a free standing form instead of an internal change on the verb stem.

Findings showed that Lari and Jibbāli use affixes to mark tenses. For example, [t]edâm] in Lari is made through [âm] which is compared to a free standing form in Jibbāli which employs $d$ (sometimes realized as ठ) to mark the progressive tense as in /tōk/. Regarding the number, it was revealed that Lari marks the various numbers by inflectional morphemes as in [æt Jom] while Jibbāli, which employs a system of dual marking, incurs internal changes into the verbs. Some verbs take an inserted vowel plus a suffix to mark conjugations. Furthermore, findings showed that marking the subjunctive mood is done via the prefix a- on the present simple with the prefix be-. Lari, on the other hand, has a different system of the transitive and intransitive verbs in which the former accepts both suffixes and prefixes while the latter just takes prefixes. However, Jibbāli uses a free standing form (not an affix) to express the subjunctive mood. [xætezbom] meaning, (if) I fell in Lari and [her shalak] meaning (if) I pour/ poured are two examples of the system in the language.

Since the languages are claimed to be endangered, it should be stressed that further research is required to examine the specific characteristics of Lari and Jibbāli. Therefore, the present study can be considered as an examination which paves the way for future research.

\section{Notes}

1- An anonymous reviewers mentions the authors neglected to review Al Aghbari's (2012) work on Jibbāli. In response to this, we would like to state that Al Aghbari's study is on the noun plurality of the language. Her study given an Optimality Theoretic analysis of plural. Our study, on the other hand, reviews works on the verbal morphologies.

2- Unless otherwise indicated, the examples listed are from the researchers' fieldworks on the languages.

\section{References}

Abolghasemi, M. (2009). Tarikh-e zaban-e Farsi. Samt Publication: Tehran, Iran.

Equtedari, A. (1990). Larestane kohan va farhange Larestani. Tehran: Jahne Moaser Publication.
Hayward, K., Hayward, R. and Al Tabuki, S.(1988). Vowels in Jibbali verbs, Bulletin of the School of Oriental and African Studies 51, 240- 250.

Hofstede, A. (1998). Syntax of Jibbali. Unpublished doctoral dissertation, University of Manchester.

Johnstone, T. (1980a). Gemination in the Jibbali language of Dhofar, Journal of Arabic Linguistics 4, 6171.

Johnstone, T. (1980b). The non-occurrence of a t-prefix in certain Jibbali verbal forms, Bulletin of the School of Oriental and African Studies XLIII(3), 466-470.

Johnstone, T. (1981). Jibbāli lexicon. London: Oxford University Press.

Khonji, L. (2009). Negaresh Tafsili bar zabane Larestani va guyeshe Khonji. Shiraz: Ilaf Press.

Lonnet, A. (1985). The Modern South Arabian languages in the P.D.R. of Yemen, Proceedings of the Seminar for Arabian Studies 15, 49-55.

Mirdehghan, M. and Muhammed, O. (2013). An analytic study of the grammatical tenses in Lari language, International Review of Social Sciences and Humanities (IRSSH)6(1), 124-134.

Moseley, C. (2010). Atlas of the world's languages in danger (3rd Ed.). Retrieved from http://unesco.org/ culture/language-atlas/

Rubin, A. D.(2008a). The sub-grouping of the Semitic languages, Language and Linguistics Compass 2, 6184.

Rubin, A. (2014). The Jibbali (Shaћari) of Oman, in A.D. Rubin and C.H.M. Versteegh (eds.). Studies in Semitic Languages and Linguistics, Volume 72.

Leiden: Brill: Boston

Vosoughi, M. B. (2006). Lar shahri be range khak . Shiraz: Kalameh.

Yule, G. (2013). The study of language (third edition). Cambridge University Press.

Equtedari, A. (2005). Zabane Larestani. Tehran: 